\title{
Traditional Knowledge System Based GIS Mapping of Antimalarial Plants: Spatial Distribution Analysis
}

\author{
Abdul Qayum 1,2*, Andrew Michael Lynn1* ${ }^{*}$, Rakesh Arya ${ }^{3}$ \\ ${ }^{1}$ Center for Biology \& Bioinformatics, School of Computational \& Integrative Sciences, Jawaharlal Nehru \\ University, New Delhi, India \\ ${ }^{2}$ Indira Gandhi National Forest Academy, Dehradun, India \\ ${ }^{3}$ Center for the Study of Regional Development, JNU, New Delhi, India \\ Email: "qayum.iitk@gmail.com, ${ }^{*}$ andrew@jnu.ac.in
}

Received 25 July 2014; revised 20 August 2014; accepted 16 September 2014

Copyright (C 2014 by authors and Scientific Research Publishing Inc.

This work is licensed under the Creative Commons Attribution International License (CC BY). http://creativecommons.org/licenses/by/4.0/

(c) (i) Open Access

\section{Abstract}

The native communities have been using their unique traditional knowledge system (TKS), culture, indigenous skills and expertise since the ancient times. India has witnessed its legacy from the time of Charaka \& Susruta for TKS of medicinal plants. The objective of the study is to carry out inter-disciplinary work by integrating ethno-medicinal findings with Geographical Information System (GIS) tools to develop spatio-temporal maps covering antimalarial plants prevalent in three rural districts of Eastern Uttar Pradesh (UP), India. Two sources Flora Gorakhpurensis \& Flora of Upper Gangetic Plains have been considered to evaluate all possible antimalarials prevalent in the study region and are cross validated with research papers and journals. GPS coordinates were recorded for marked locations and under GIS environment maps of antimalarials are generated to highlight geographical distribution of such plants. Further, these are analysed with respect to various natural plant habitats. 48 plants belonging to 25 families were found and its geographical distribution is illustrated through series of GIS maps. The developed map highlights the geographical location of antimalarial plants and facilitates easy access of plant's natural habitat. It is believed that the work would help researchers to find out the novel antimalarials towards open source drug discovery projects.

\section{Keywords}

Antimalarial Plants, Bio-Prospecting, Geographical Distribution, GIS Mapping, Medicinal Plants, Vector Borne Disease

\footnotetext{
${ }^{*}$ Corresponding authors.
} 


\section{Introduction}

There is increased biotic pressure due to excessive increase in human population and over harvesting of nature and natural resource, resulting in increased attention to bio-prospecting [1]. The potential for physical flora collection to support scientific research is being enhanced by rapid development of information technology and remotely available digital database. India possesses rich floristic wealth and diversified genetic resources of medicinal plants. Several plants are used in traditional medicine for the treatment of vector borne diseases including malaria in many parts of the world [2]. Modern drugs have been deducted from folklore and traditional medicines [3] and hence the search for additional antimalarials from higher plants must continue to fight the deadly disease.

About 36\% of world population is at risk of malaria. Around 2.5 million malaria cases are reported annually from South East Asia and 76\% of it is in India (WHO, 2011). In the Tarai region of Eastern UP the spreading of vector borne diseases become uncontrolled especially during rainy seasons [4]. The need of the hour is to find new variety of drugs to combat the attack of mosquitoes who have found resistance to almost all old drugs. GIS provides the architecture and analysis tools to perform spatio-temporal modeling of disease transmission, and other factors relevant to the understanding of impacts and risk associated with malaria [5]. The effort has to be finding an alternative form of malaria control. Cost effective, practical and accessible interventions to be integrated into most malaria control programs. And thus investigation of insecticidal properties of plant-derived materials is environmentally safe, degradable and target specific.

Based on the parameters, like the recorded uses of medicinal plants, rarity and threat factors plant species and area can be identified to develop GIS based mapping using available software for visualizing, analyzing, creating, and managing data with a geographic component. Most data has a component that can be tied to a place using global positioning system (GPS) co-ordinates. GIS has been used as a "map maker” [6]. GIS supports multidisciplinary analysis using a systematic approach and provides the ability to perform predictions of disease outbreaks based on available information. Later, plant density can also be calculated using image analysis algorithm applied on satellite data, and it can be cross validated with the available government data of forest of that area.

The trade in herbs and medicinal plants in UP at present stands at \$1000 million per annum approximately. The growth rate has increased from $7 \%$ to $15 \%$ in the last couple of years, but export from the state is extremely inferior. In UP, over 250,000 hectare land comes under cultivation of herbs. The demand for herbal and natural products is escalating globally. The international market of herbal products is estimated above $\$ 62$ billion while India's share in the global market of export is merely 0.5\% (Economic policy Business Standard 2009) [7]. The demand for the high time is to explore several means and launch various bio-prospecting projects to harvest natural wealth of the country sustainably. State government of UP has taken various initiatives towards meeting herbal and medicinal needs of people including cultivation of antimalarial medicinal plant Artemisia annua by Central Institute of Medicinal and Aromatic Plants (CIMAP) Lucknow. It is used to extract artemisinin, a compound which is most widely used compound in the development of antimalarial drug.

Ethnobotanical exploration with respect to food value has been done for north-eastern tarai region of UP and found 27 underutilized edible fruits consumed by ethnic people [8]. It widens the scope of bio-prospection and has established database of these fruits may be helpful in for achieving food security and environmental sustainability. For north east India all the antimalarial plants have been enlisted to emphasize the need for an alternative drug for malaria for developing new indigenous antiplasmodic plants [9]. It has also been highlighted total herbal plants used for the treatment of malaria and found that many of these plants are being used since ancient times for the treatment of malaria throughout the world [10].

The current work is an amalgamation of data collection and its cross validation. It is based on two sources namely “Flora Gorakhpurensis” \& “Flora of Upper Gangetic Plains” and cross validated with available literature survey (Figure 1). This is done to evaluate future prospects of all antimalarials prevalent in the region. Available literature amounts to numerous research papers and journals related such work of compilation of antimalarial plants and GIS applications. From the study area 48 antimalarial plants were reported. GPS coordinates were recorded for marked locations and under GIS environment maps of antimalarials are generated to highlight geographical distribution of such plants. Further, these are analysed with respect to various natural plant habitats. Having life in close vicinity of the nature, traditional societies have acquired unique knowledge about the use of flora and fauna in wild, most of which are still unknown to the common masses. The traditional knowledge, skills and practices thus developed are freely exchanged, cared for and nourished as a common property of the 


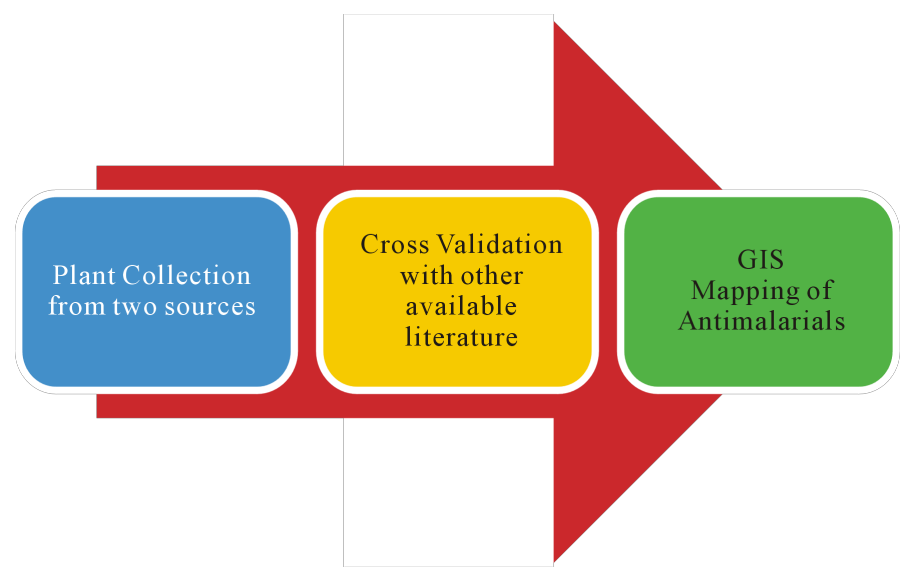

Figure 1. Work strategy.

communities [11]. The current work has highlighted the geographical location (habitat) of antimalarial plants along with other details like plant species, plant family and local name.

The objective of the current study is to carry out inter-disciplinary work by integrating ethno-medicinal findings with GIS tools to develop spatio-temporal maps covering antimalarial plants prevalent in three rural districts of eastern UP, India. Further, the aim is to adapt and apply map design principles to minimize cognitive and perceptual burden of exploring complex data sets. Spatial distribution of malaria using GIS happens to be a de novo approach in defining plants of a given locality and the advancement in information technology will certainly give an edge to this emerging field of research.

\section{Materials and Methods}

\subsection{Study Area}

The study area outlines three rural (Rural Population: 88.53\%) districts of north-eastern corner of the most populous state of UP, India (Figure 2) with 3.82\% state area. It is surrounded by rivers Rapti (tributary to the Gandak) and Rohini. Geographical extension of three districts are; Gorakhpur (Lat. 26 $13^{\circ} \mathrm{N}$ to $27^{\circ} 29^{\prime} \mathrm{N}$ and Long. $83^{\circ} 05^{\prime} \mathrm{E}$ to $83^{\circ} 56^{\prime} \mathrm{E}$ ), Kushinagar (Lat. $26^{\circ} 39^{\prime} \mathrm{N}$ to $27^{\circ} 15^{\prime} \mathrm{N}$ and Long. $83^{\circ} 38^{\prime} \mathrm{E}$ to $84^{\circ} 15^{\prime} \mathrm{E}$ ) and Maharajganj (Lat. $26^{\circ} 59^{\prime} \mathrm{N}$ to $27^{\circ} 19^{\prime} \mathrm{N}$ and Long. $83^{\circ} 09^{\prime} \mathrm{E}$ to $83^{\circ} 45^{\prime} \mathrm{E}$ ). It also shares international border with Nepal. The study area is home to $10,690,142$ people of Indian masses with $48.60 \%$ female population and 1,680,587 as total house hold of which $87.98 \%$ is rural house hold [12]. Study area belongs to low socio-economic zone [13] with 3,462,855 total work participation (Female: 28.3\%) \& 1,708,932 main work participation (Female: 19.1\%) and 1,753,923 marginal worker (Female: $37.3 \%$ ) while monthly income is 70.3 USD and population is merely agrarian (97.48\%) with 87,400 main industry working.

\subsection{Data Collection}

Two sources Flora Gorakhpurensis [14] \& Flora of Upper Gangetic Plains [15] have been considered to evaluate all possible antimalarials prevalent in the study region and are cross validated with numerous research papers and journals. GPS coordinates were recorded for marked locations and under GIS environment maps of antimalarials are generated to highlight geographical distribution of such plants. Further, these are analysed with respect to various natural plant habitats. To evaluate plants distribution a pie chart (Figure 3) has been drawn for plants present in various habitats.

\subsection{Methodology}

Study is based on extraction of ethno-medicinal utilities of plants based on two sources and cross examined with traditional knowledge (TK) available in relevant literatures [3] [9] [16]-[22] including various research papers \& journals to obtain Table 1. For geographical location; GPS (Global Positioning System) coordinates were recorded. The GIS Maps were generated through satellite imageries, plant location description and GPS observa- 
Table 1. Antimalarial plants prevalent in the study area.

\begin{tabular}{|c|c|c|c|c|}
\hline S. No. & Plant species & Family & Local name & Plant habitat \\
\hline 1 & Abrus precatorius Linn. & Fabaceae & Ratti, Ghumchi & Fruit orchard \& climbing over trees. \\
\hline 2 & Acacia farnesiana (L.) Willd. & Fabaceae & Tarua kadam (Ass) & $\begin{array}{l}\text { Found wild in wastelands, } \\
\text { cultivated in gardens. }\end{array}$ \\
\hline 3 & Achyranthes aspera Linn. & Amaranthaceae & Chirchita/Apamarga/Chitchita & $\begin{array}{l}\text { Roadsides, hills up to } 900 \text { m, } \\
\text { Railway lines, wastelands. }\end{array}$ \\
\hline 4 & Adhatoda vasica Nees & Acanthaceae & Arusa/Vasaka & $\begin{array}{l}\text { Cultivated lands, Waste places \& } \\
\text { Railway tracks. }\end{array}$ \\
\hline 5 & $\begin{array}{l}\text { Aerva lanata (L.) } \\
\text { Juss. ex Schult. }\end{array}$ & Amaranthaceae & Gorakhganja/Bhadra & Weed of crop fields, in fruit orchards. \\
\hline 6 & Alstonia scholaris (L.) R.Br. & Apocyanaceae & Saptaparna/Saptachada/chatiyan & $\begin{array}{l}\text { Planted as roadside tree } \& \\
\text { also found wild. }\end{array}$ \\
\hline 7 & $\begin{array}{l}\text { Alternanthera sessilis } \\
\text { (L.) R.Br. ex DC. }\end{array}$ & Amaranthaceae & Gudrisag/Matsyaksi & $\begin{array}{l}\text { Weed of cultivated field \& } \\
\text { in moist waste places. }\end{array}$ \\
\hline 8 & Amaranthus spinosus Linn. & Amaranthaceae & Chaulai Bhaji, Cholai & $\begin{array}{l}\text { Along roads, canals, railway tracks \& } \\
\text { weed of cultivated fields. }\end{array}$ \\
\hline 9 & Ammannia baccifera Linn. & Lythraceae & Dadamari & $\begin{array}{l}\text { Marshy lands, Paddy fields, } \\
\text { moist places }\end{array}$ \\
\hline 10 & $\begin{array}{l}\text { Andrographis paniculata } \\
\text { Wall. ex Nees }\end{array}$ & Acanthaceae & Kalmegh & Shady waste grounds. \\
\hline 11 & $\begin{array}{l}\text { Asteracantha longifolia (L.) } \\
\text { Nees }\end{array}$ & Acanthaceae & Talmakhana & Shallow ditches along roads. \\
\hline 12 & Azardirachta indica A. Juss & Meliaceae & Neem & Planted in gardens \& near temples. \\
\hline 13 & Barleria prionitis Linn. & Acanthaceae & Kastira, Bajradanti & Waste ground, planted as border plant. \\
\hline 14 & Bauhinia variegata Linn. & Fabaceae & Kachnar & Planted in gardens \& as roadside tree. \\
\hline 15 & $\begin{array}{l}\text { Boerhaavia diffusa } \\
\text { L.nom.cons. }\end{array}$ & Nyctaginaceae & Gadapurna/Punarnava & $\begin{array}{l}\text { Elevated lands, roadsides, railway } \\
\text { tracks, waste places, crevices } \\
\text { of walls \& orchards. }\end{array}$ \\
\hline 16 & Caesalpinia crista (Linn.) & Fabaceae & Kat-karanj, Karanju & Open wastelands \& along Nallas. \\
\hline 17 & Carica papaya Linn. & Caricaceae & Papita & $\begin{array}{l}\text { Cultivated around bungalows } \\
\text { \& gardens. }\end{array}$ \\
\hline 19 & Cissampelos pareira Linn. & Menispermaceae & Harjuri, Bharatbuti & $\begin{array}{l}\text { Fruit orchard, \& as hedges of } \\
\text { parks \& gardens. }\end{array}$ \\
\hline 20 & Citrus medica Linn. & Rutaceae & Jamerinimbu & Planted in Gardens, Lahladpur area. \\
\hline 21 & $\begin{array}{l}\text { Clerodendron infortunatum } \\
\text { Linn. }\end{array}$ & Verbenaceae & Bhat & Under shades of trees, fruit orchards. \\
\hline 22 & Cuscuta reflexa Roxb. & Convolvulaceae & Amarbel & $\begin{array}{l}\text { Twining upon Adhatoda vasica, } \\
\text { near Surajkund, Tiwaripur region. }\end{array}$ \\
\hline 23 & Cyperus scariosus Br. & Cyperaceae & Nagarmotha/Chakranksha & Shallow water bodies of study area. \\
\hline 24 & Datura metel Linn. & Solanaceae & Dhatura & Frequently in waste places. \\
\hline 25 & Eclipta prostrata (Linn.) Linn. & Asteraceae & Bhangraiya, Bhringaraj & $\begin{array}{l}\text { Open pastures, wet regions, } \\
\text { along water canals. }\end{array}$ \\
\hline
\end{tabular}




\section{Continued}

\begin{tabular}{|c|c|c|c|c|}
\hline 26 & Erythrina variegata Linn. & Fabaceae & Pangara & $\begin{array}{l}\text { Moderate sized deciduous tree planted } \\
\text { in gardens, Near Ramgarh tal. }\end{array}$ \\
\hline 27 & Jatropha gossypifolia Linn. & Euphorbiaceae & Bhakrend & $\begin{array}{l}\text { Roadside weed \& found at } \\
\text { other waste ground. }\end{array}$ \\
\hline 28 & Lantana camara Linn. & Verbenaceae & Ghaneri & $\begin{array}{l}\text { Roadsides, Wild, Wastelands } \\
\text { \& Railway colony. }\end{array}$ \\
\hline 29 & Leucas aspera (Willd.) Link. & Lamiaceae & Gopha, Drona pushpi & $\begin{array}{l}\text { Weed of crop field, waste places, } \\
\text { dry open sandy soil, Bhathat region. }\end{array}$ \\
\hline 30 & $\begin{array}{l}\text { Ludwigia octovalvis } \\
\text { (Jacq.) P.H. Raven }\end{array}$ & Onagraceae & Panijalokia & Wet places, sides of tanks. \\
\hline 31 & Magnolia grandiflora Linn. & Magnoliaceae & Andachampa & $\begin{array}{l}\text { Planted in gardens, } \\
\text { Gorakhnath temple area. }\end{array}$ \\
\hline 32 & Momordica charantia Linn. & Cucurbitaceae & Kathnim, Karavellaka & $\begin{array}{l}\text { Cultivated, found wild, } \\
\text { climbing on hedges. }\end{array}$ \\
\hline 33 & Murraya koenigii (L.) Sprengel & Rutaceae & Bursunga/Gandhla & $\begin{array}{l}\text { Deciduous shrub on waste grounds along } \\
\text { water bodies, planted in gardens. }\end{array}$ \\
\hline 34 & Nyctanthes arbortristis Linn. & Oleaceae & Harsingar & $\begin{array}{l}\text { Gardens, Bungalow, Temple } \\
\text { \& Railway colonies. }\end{array}$ \\
\hline 35 & Ocimum sanctum Linn. & Lamiaceae & Tulsi & $\begin{array}{l}\text { Found as an escape from cultivation } \\
\text { in moist places. }\end{array}$ \\
\hline 36 & Oenanthe javanica (BL.) DC. & Apiaceae & Pan tarori & $\begin{array}{l}\text { Weed in moist waste places, fruit } \\
\text { orchards, along water channels. }\end{array}$ \\
\hline 37 & Pongamia pinnata (L.) Pierre & Fabaceae & Karanja & $\begin{array}{l}\text { Roadside, near Canals, Wasteland, Moist } \\
\text { regions, Pharenda \& Ramgarh forest. }\end{array}$ \\
\hline 38 & Putranjiva roxburghii (Wall.) & Euphorbiaceae & Putjev, Jiaputa, Putrajiva & $\begin{array}{l}\text { Wild, tropical \& cultivated, } \\
\text { hedge plants in gardens. }\end{array}$ \\
\hline 39 & $\begin{array}{l}\text { Rauvolfia serpentine } \\
\text { (Linn.) Benth. }\end{array}$ & Apocynaceae & Dhamarharua & Damp places, wild in forests. \\
\hline 40 & Scoparia dulcis Linn. & Scrophulariaceae & Mithi patti & Waste places \& a weed of crop fields. \\
\hline 41 & Sida rhombifolia Linn. & Malvaceae & Bariara & $\begin{array}{l}\text { Shady waste places near tals } \\
\text { (water bodies), hedges. }\end{array}$ \\
\hline 42 & Solanum indicum Linn. & Solanaceae & Lapta Brihatti, Banbhanta & Found as wild in whole study area. \\
\hline 43 & $\begin{array}{l}\text { Stephania japonica } \\
\text { (Thunb.) Miers. }\end{array}$ & Menispermaceae & Rajpatha & Hedges on moist ground. \\
\hline 44 & Streblus asper Lour. & Moraceae & Singhor & $\begin{array}{l}\text { Small evergreen tree found } \\
\text { throughout. }\end{array}$ \\
\hline 45 & $\begin{array}{l}\text { Tinospora cordifolia } \\
\text { (Thunb.) Miers. }\end{array}$ & Menispermaceae & Gurch, Giloe & $\begin{array}{l}\text { On hedges \& trees, tropical } \\
\text { regions of study area. }\end{array}$ \\
\hline 46 & Vandellia sessiliflora Benth. & Scrophulariaceae & Lindernia sp. Indian & $\begin{array}{l}\text { Damp \& shady places, } \\
\text { grows with grasses. }\end{array}$ \\
\hline 47 & Vernonia cinerea (Linn.) Less. & Asteraceae & Sahdevi & Weed of crop field \& waste grounds. \\
\hline 48 & Xanthium strumarium Linn. & Asteraceae & Lapetua & $\begin{array}{l}\text { Waste places, long railway } \\
\text { tracks \& roadsides. }\end{array}$ \\
\hline
\end{tabular}




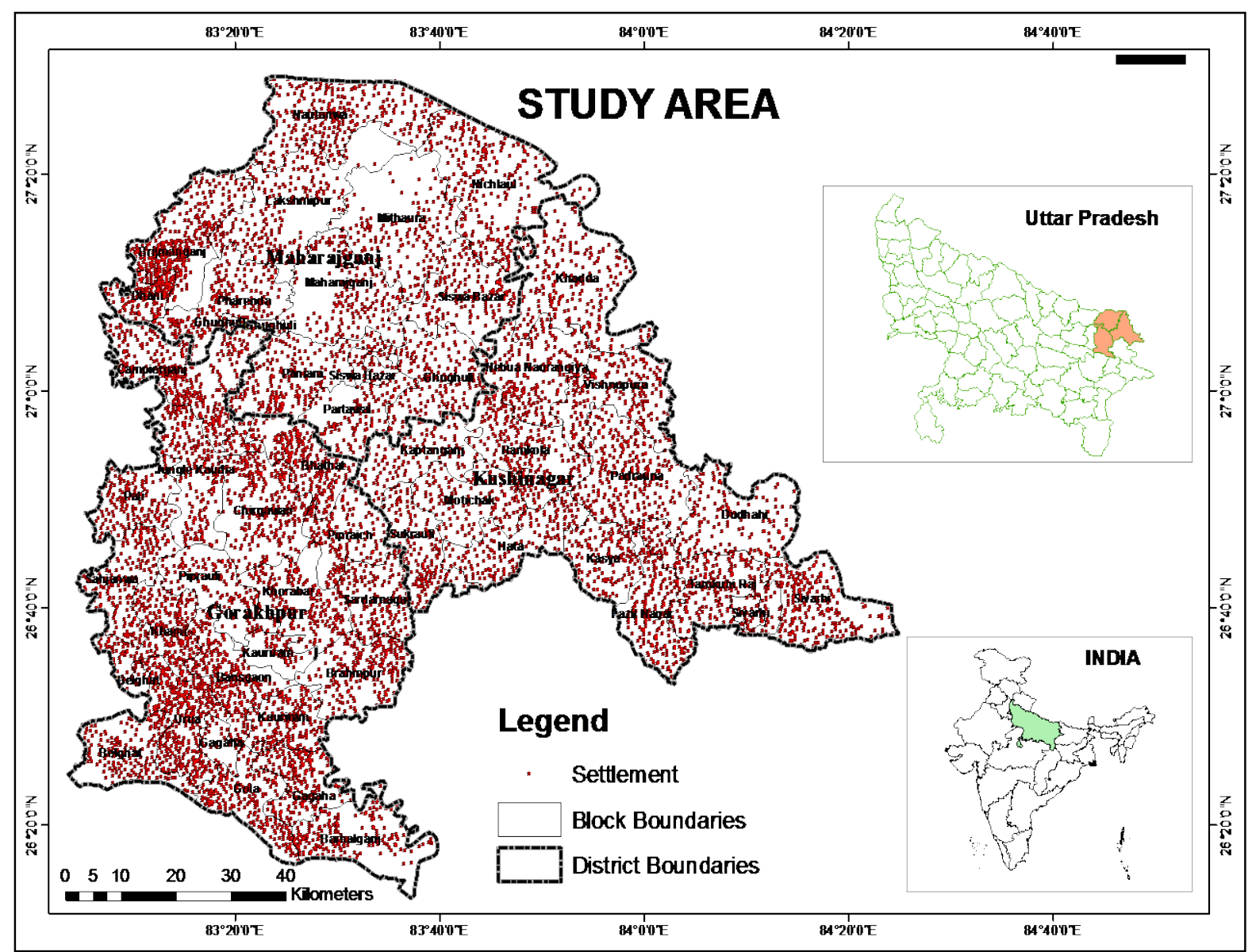

Figure 2. Location of study area.

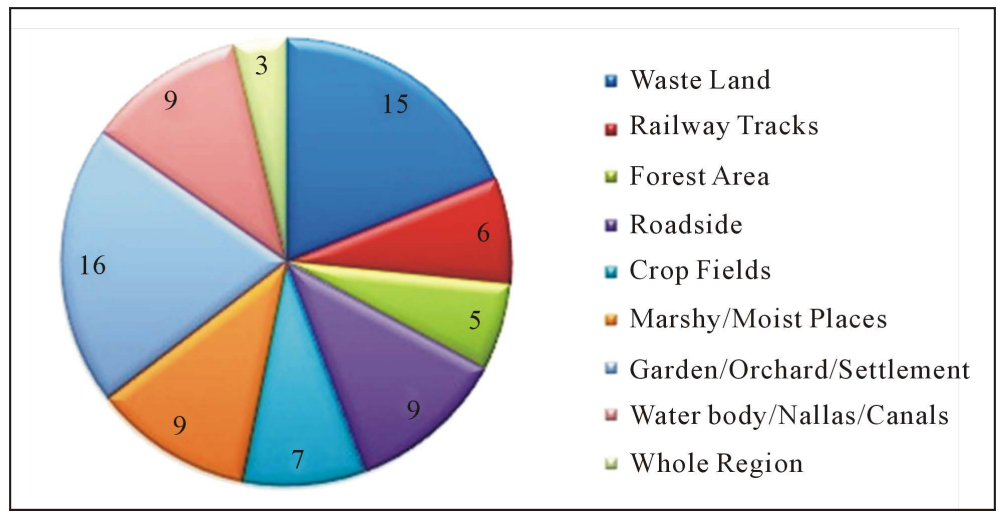

Figure 3. Plant distribution in various habitats.

tions using ArcGIS 10.

\subsection{GIS Mapping}

The distribution of antimalarial plants is mapped based on references drawn from available literature, operational land imager (OLI) satellite imagery and limited field verification using GPS. The data collected from mentioned sources is integrated in ArcGIS 10 environment. Further, it is extrapolated over similar geographical environment using satellite imageries. 


\section{Results}

\subsection{Ethnobotanical Data}

48 plants belonging to 25 families were found and its geographical distribution is illustrated through series of GIS based maps (Figure 4 to Figure 8). These developed maps highlight the geographical location of antimalarial plants and facilitates easy access of plant's natural habitat. The collected plant data has been charted (Table 1) in order of plant species, plant family local name \& plant habitat.

Also, geographical profile (Figure 9) of study area has been established to understand natural resources present in the region. The legend in this map accounts for various types of vegetation prevalent, water body present, man-made structures, settlements etc. Mapping is done to minimize cognitive and perceptual burden of complex data sets.

\subsection{GIS Mappings for Spatial Distribution}

All 48 antimalarial plants of the study area are grouped in five GIS maps (Figure 4 to Figure 8) based on similar types of habitat. Legends in each map signify botanical names of plant prevalent in that region. The grouping of antimalarial plants in various GIS maps is based to maintain maximum presentation of their geographical extent as many antimalarial plants are not confined to only one geographical region. Figure 4 shows the distribution of plants usually found in the tree/forest, open pastures, river and water body regions. Figure 5 shows plants found in some specific locations like Lahladpur, Surajkund, Tiwaripur, Ramgarh Tal, Gorakhnath Temple, Pharenda (forest), Ramgarh (forest), Paniara, Bhathat areas whereas, in the same map plants mainly found in forest near tals and some found vaguely throughout the region are also shown.

The distribution of plants that are found in fruit orchards, waste/open areas and along railway tracks has also been shown (Figure 6) and the plants that are distributed in moist waste places, crop fields and along roadside are geographically represented (Figure 7) while the distribution of antimalarial plants in marshy lands, moist places, garden and temples (in settlements) and near nallas/canals are represented nicely using GIS (Figure 8).

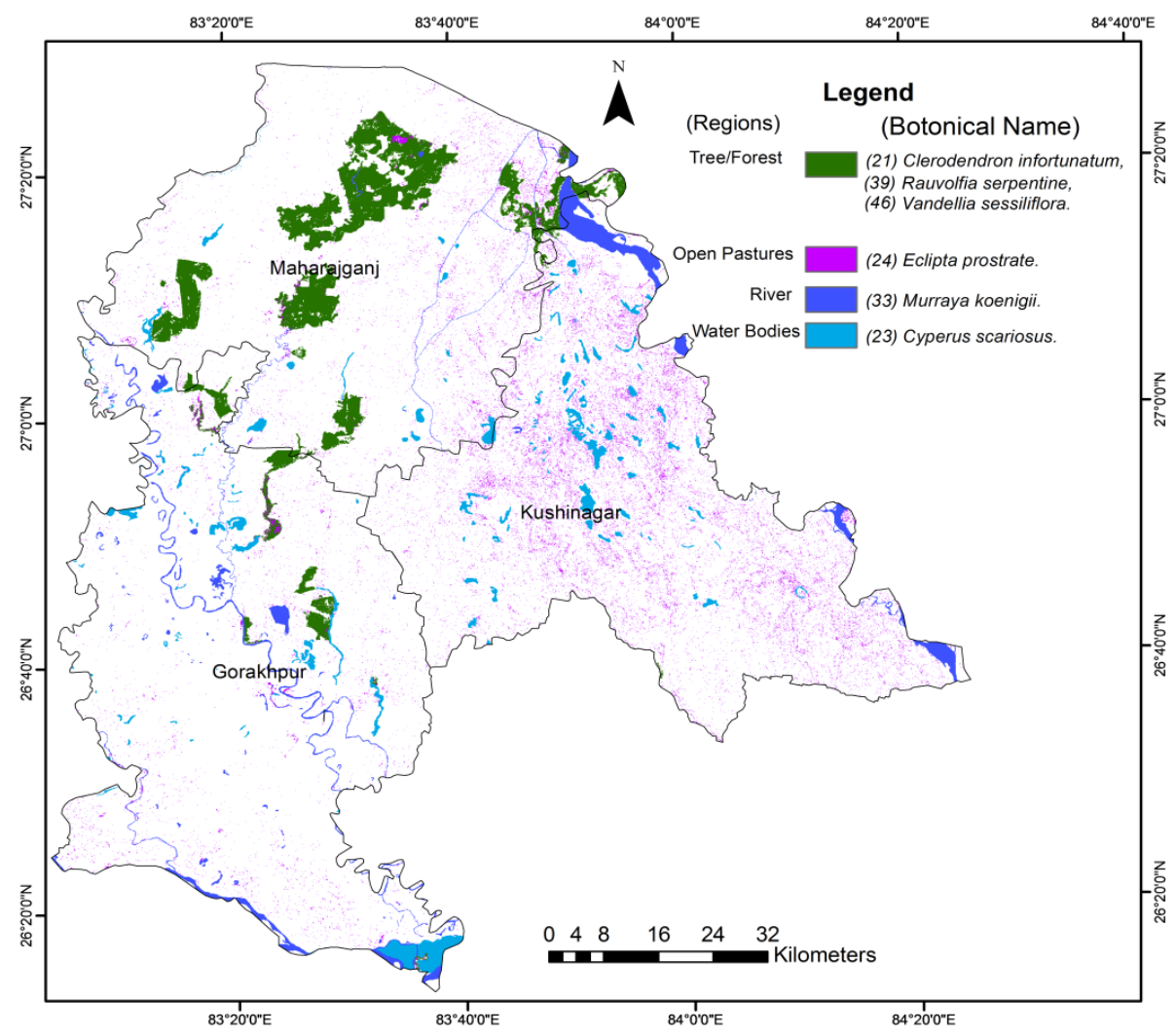

Figure 4. Antimalarials in forest \& near water bodies. 


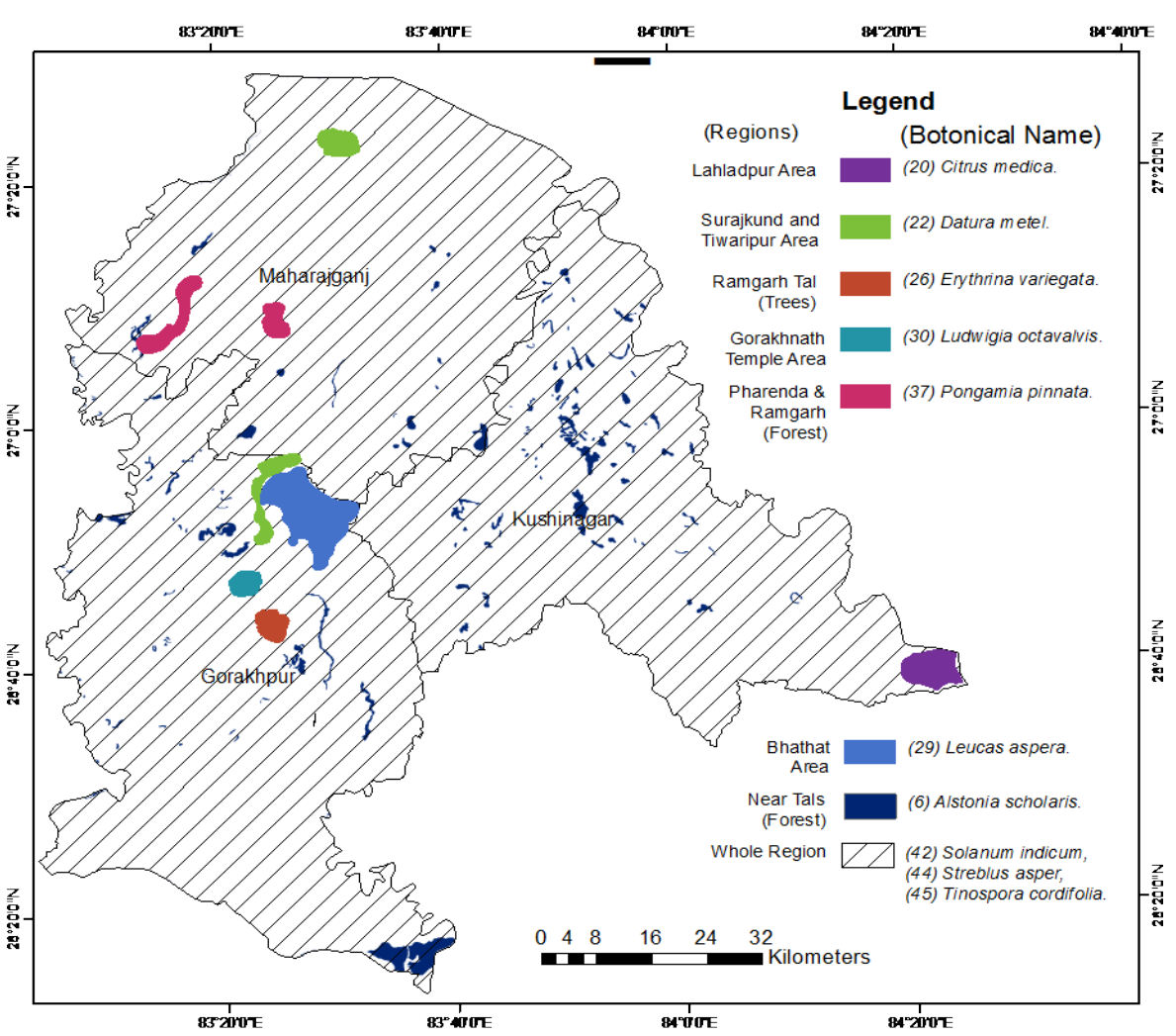

Figure 5. Antimalarials found throughout area \& some specific locations.

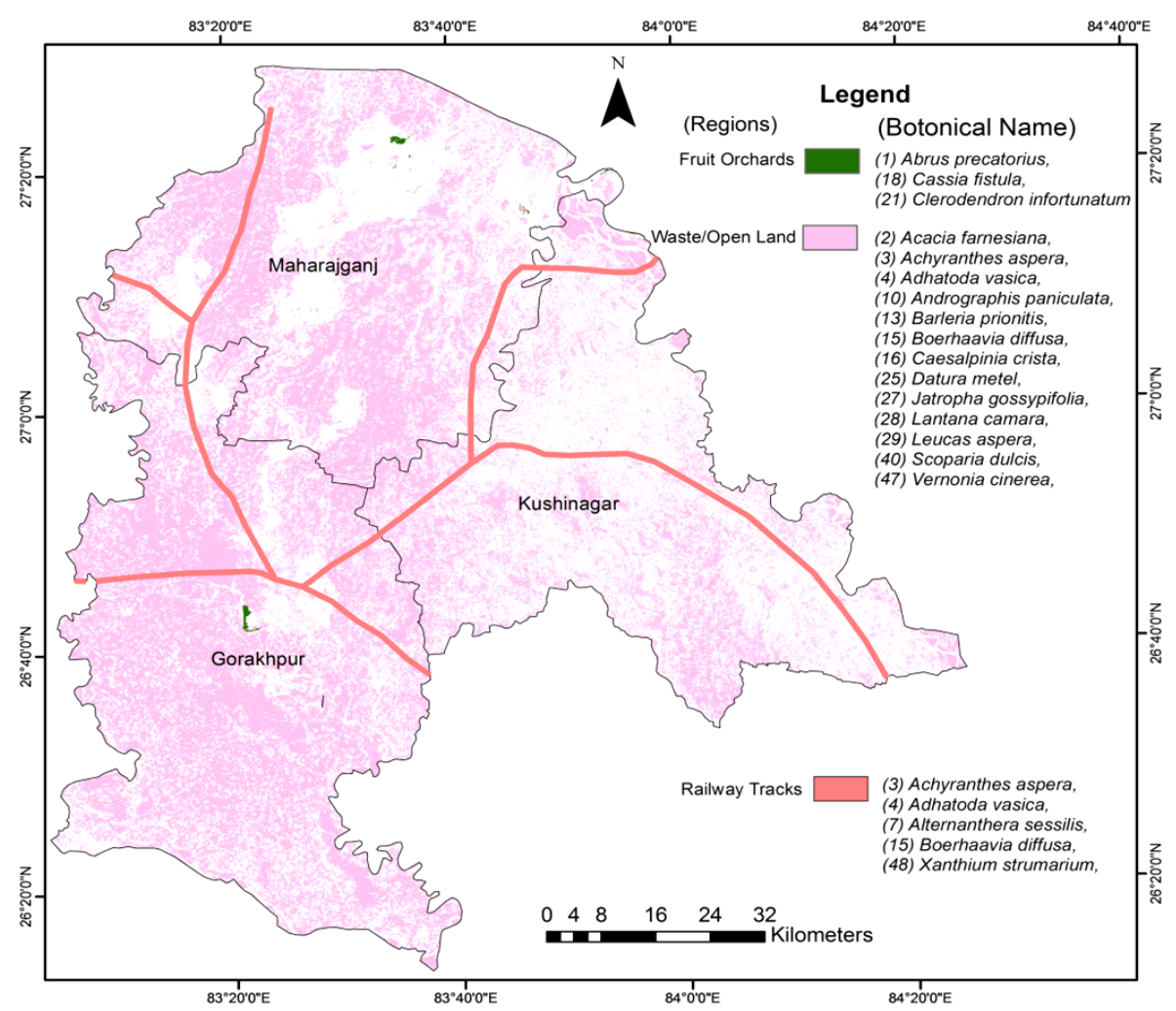

Figure 6. Antimalarials of orchards, waste lands \& railway tracks. 


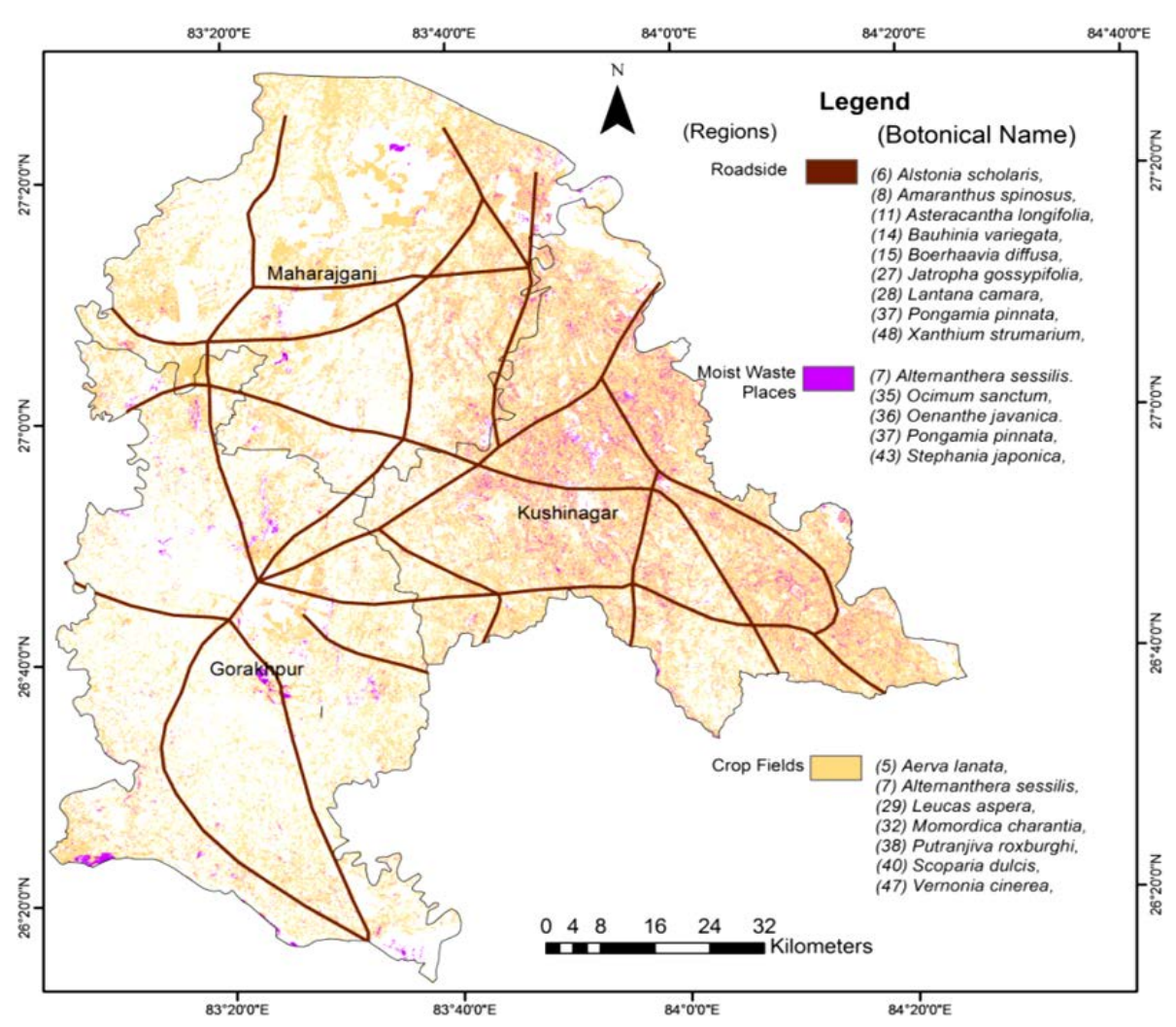

Figure 7. Antimalarials found in crop fields, roadsides \& moist waste places.

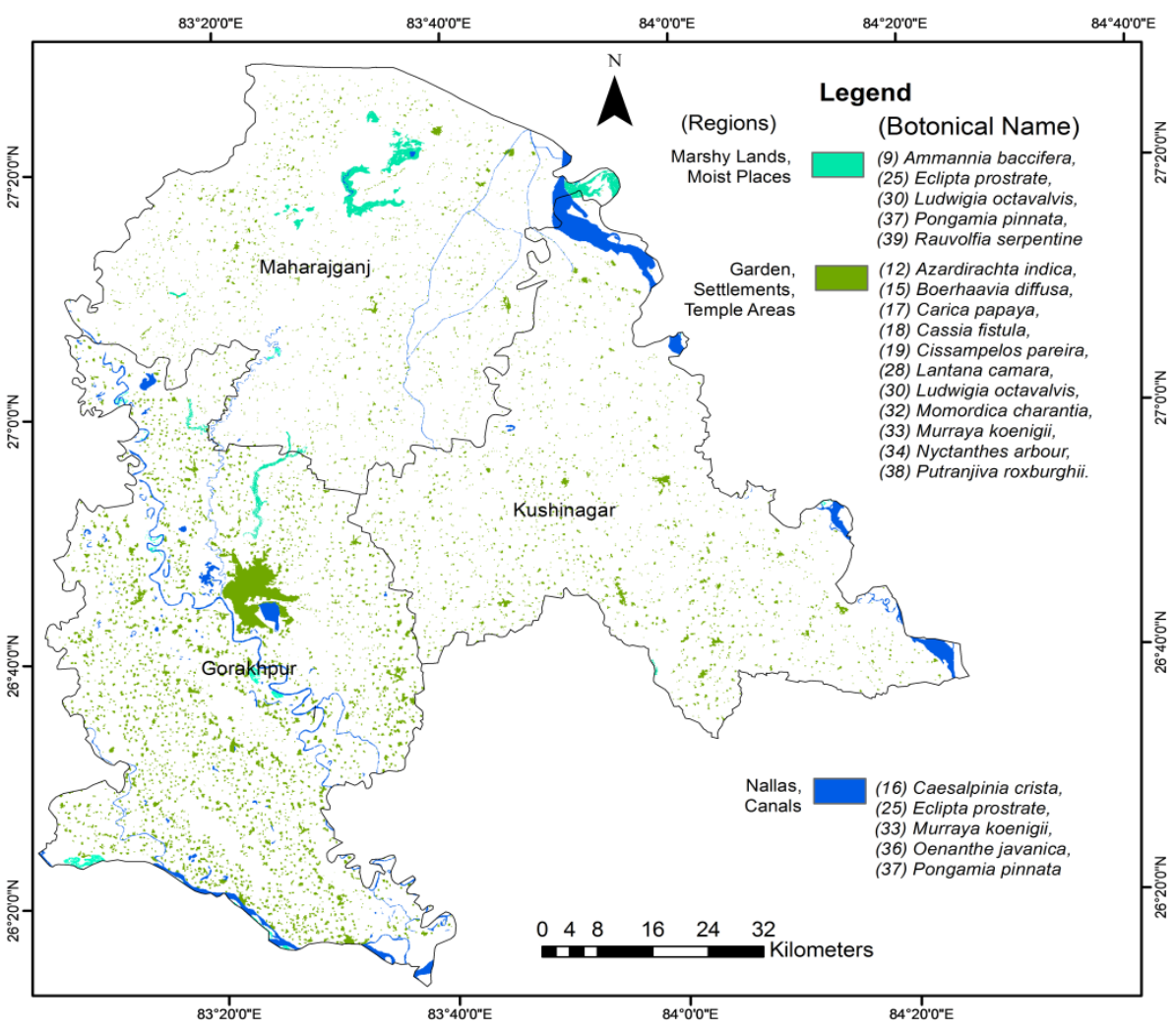

Figure 8. Antimalarials found in marshy, settlement \& water bodies. 


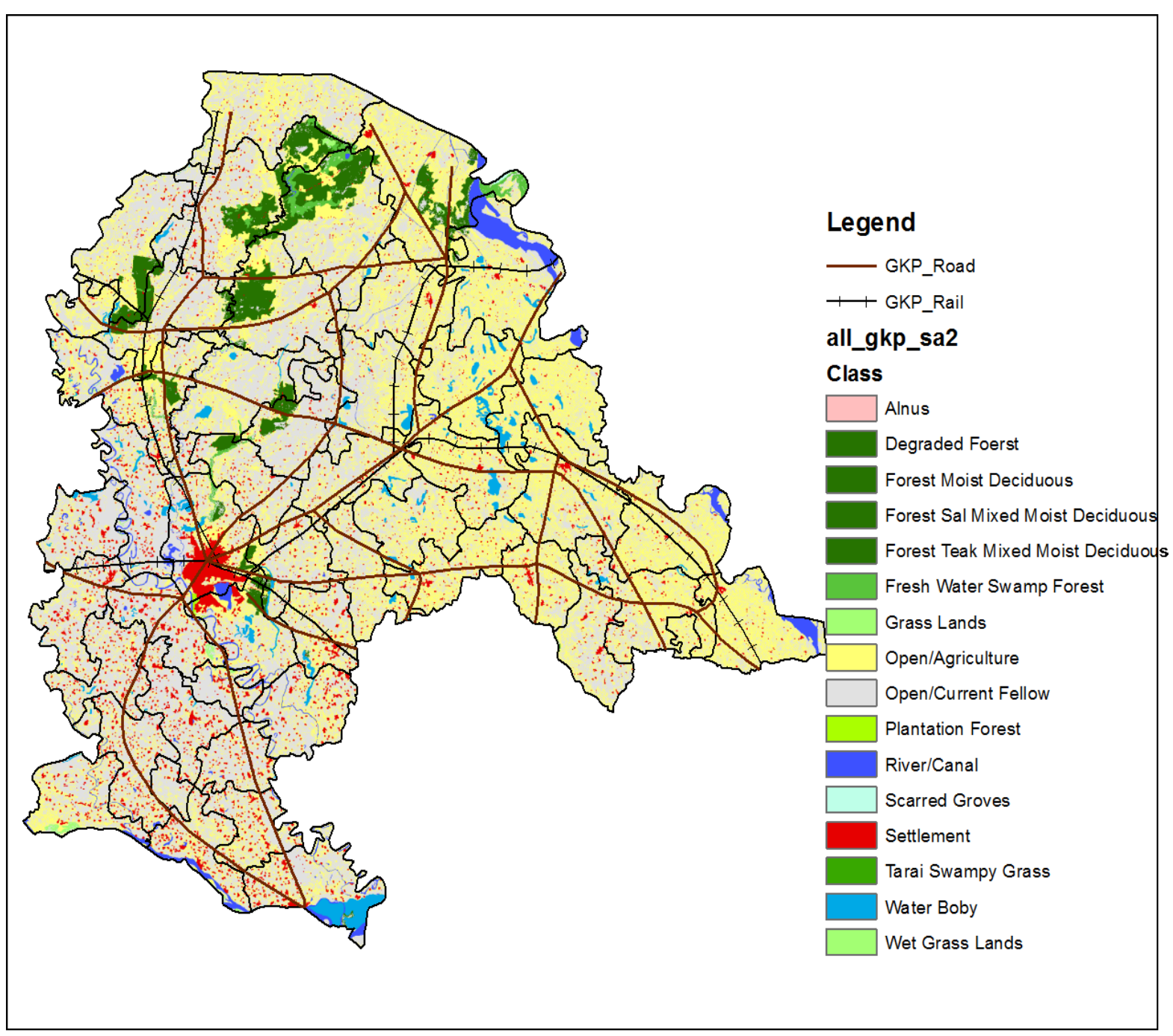

Figure 9. Geographical profile of study area.

Availability of any particular antimalarial plant can be easily traced across these maps using both legends of the map.

\section{Discussion}

The work is not purely ethnobotanical in nature but amalgamation of ethnobotany \& GIS. It is the work of ethnography. The native communities have been using their unique traditional knowledge system, culture, indigenous skills and expertise since the ancient times. India has witnessed its legacy from the time of Charaka \& Susruta for traditional knowledge system (TKS) of medicinal plants. The GIS map has facilitated easy access of plant's natural habitat. Further, it depicts the importance and method of application of these plants towards treatment in case of malaria, fever and intermittent fever. Applying GIS mapping will catalyse the process of extraction of artemisinin \& quinine derivatives from the antimalarial plants and it will be a novice idea especially with the growing importance of information technology and advancement in satellite imagery techniques. This region has monsoonal rainfall that makes it favourable for vector borne diseases and hence the traditional knowledge coupled with new technology makes this study highly useful for basic amenity stressed regions.

Geographical distribution has been fragmented to eight habitat types (Table 2) of waste land (WL-15 plants), railway tracks (RL-6 plants), forest area (FA-5 plants), Roadside (RD-9 plants), Marshy/Moist Places (MM-9), crop fields (CF-7 plants), Garden/Orchard/Settlement (GOS-16 plants), water body/nallas/canals (WB-9 plants), 
Table 2. Distribution of plant in various natural habitats.

\begin{tabular}{llllllllllllll}
\hline \multirow{2}{*}{ Plant species } & \multicolumn{1}{l}{ Natural habitats of plants } \\
\cline { 2 - 7 } & WL & RL & FA & RD & MM & CF & GOS & WB & WR \\
\hline
\end{tabular}

Abrus precatorius Linn.

Acacia farnesiana (L.) Willd. $\quad \sqrt{ }$

Achyranthes aspera Linn.

Adhatoda vasica Nees

Aerva lanata (L.) Juss. ex Schult.

Alstonia scholaris (L.) R.Br.

Alternanthera sessilis (L.) R.Br.ex DC. $\quad \sqrt{ }$

Amaranthus spinosus Linn.

Ammannia baccifera Linn.

$\sqrt{ }$

$\sqrt{ } \quad \sqrt{ }$

$\sqrt{ } \quad \sqrt{ }$

Andrographis paniculata Wall. Nees

Asteracantha longifolia (L.) Nees

Azardirachta indica A.Juss

Barleria prionitis Linn.

Bauhinia variegata Linn.

Boerhaavia diffusa L.nom.cons.

Caesalpinia crista (Linn.)

Carica papaya Linn.

Cassia fistula Linn.

Cissampelos pareira Linn.

Citrus medica Linn.

Clerodendron infortunatum Linn.

Cuscuta reflexa Roxb.

Cyperus scariosus Br.

Datura metel Linn.

Eclipta prostrata (Linn.) Linn.

Erythrina variegata Linn.

Jatropha gossypifolia Linn.

Lantana camara Linn

Leucas aspera (Willd.) Link.

Ludwigia octovalvis (Jacq.) P.H.Raven

Magnolia grandiflora Linn.

Momordica charantia Linn.

Murraya koenigii (L.) Sprengel

Nyctanthes arbor-tristis Linn. $\sqrt{ }$

$\sqrt{ }$

$\sqrt{ }$

$\sqrt{ }$

$\sqrt{ }$

$\checkmark$

$\sqrt{ }$

$\sqrt{ }$

$\checkmark$

$\sqrt{ }$

$\sqrt{ }$

$\sqrt{ }$

$\sqrt{ }$

$\sqrt{ }$

$\sqrt{ }$

$\sqrt{ } \quad \sqrt{ }$

$\checkmark$

$\sqrt{ }$

$\sqrt{ }$

V

$\sqrt{ }$

$\sqrt{ } \quad \sqrt{ }$

$\checkmark \quad V$

V 


\begin{tabular}{|c|c|c|c|c|c|c|c|c|c|}
\hline Continued & & & & & & & & & \\
\hline Ocimum sanctum Linn. & & & & & $\sqrt{ }$ & & & & \\
\hline Oenanthe javanica (BL.) DC. & & & & $\sqrt{ }$ & & & $\sqrt{ }$ & & \\
\hline Pongamia pinnata (L.) Pierre & & $\sqrt{ }$ & $\sqrt{ }$ & $\sqrt{ }$ & & & $\sqrt{ }$ & & \\
\hline Putranjiva roxburghii (Wall.) & & & & & $\sqrt{ }$ & $\sqrt{ }$ & & & \\
\hline Rauvolfia serpentine (Linn.) Benth. & & $\sqrt{ }$ & & $\sqrt{ }$ & & & & & \\
\hline Scoparia dulcis Linn. & $\sqrt{ }$ & & & & & $\sqrt{ }$ & & & \\
\hline Sida rhombifolia Linn. & $\sqrt{ }$ & & & & & & & $\sqrt{ }$ & \\
\hline Solanum indicum Linn. & & & & & & & & & $\sqrt{ }$ \\
\hline Stephania japonica (Thunb.) Miers. & & & & $\sqrt{ }$ & & & & & \\
\hline Streblus asper Lour. & & & & & & & & & $\sqrt{ }$ \\
\hline Tinospora cordifolia (Thunb.) Miers. & & & & & & & & $\sqrt{ }$ & \\
\hline Vandellia sessiliflora Benth. & & & $\sqrt{ }$ & & & & & & \\
\hline Vernonia cinerea (Linn.) Less. & $\sqrt{ }$ & & & & & $\sqrt{ }$ & & & \\
\hline Xanthium strumarium Linn. & & $\sqrt{ }$ & & $\sqrt{ }$ & & & & & \\
\hline
\end{tabular}

$\mathrm{WL}=$ Waste Land, RL = Railway Tracks, FA = Forest Area, RD = Roadside, MM = Marshy/Moist Places, CF = Crop Fields, GOS = Garden/Orchard/Settlement, WB = Water Body/Nallas/Canals, WR = Whole Region.

whole region (WR-3 plants). There are many plants found in more than one habitat type. Largest number of plants is found in gardens, orchard and settlements while as many as 15 plants are found in waste lands. There are three plants Solanum indicum, Streblus asper and Tinospora cordifolia which are found throughout the study area \& in abundance (Figure 5). In the study area two species namely Nagarmotha (Cyperus scariosus) and Goma or Drona pushpi (Leucas aspera) are at the verge of extinction mainly due to the change in water reservoir structure i.e. because of loss of water bodies like ponds and other reservoirs for the former and because of change in land-use pattern for the latter. Further, due to ruthless exploitation, many important medicinal plants species are becoming rare and some of them are critically endangered (As per the IUCN, Switzerland Red List Criteria). It is estimated that $10 \%$ of all plant species are currently endangered in India [19].

Herbal medicines have good values in malaria treatment and because of its potential in many countries scientific investigations are undergoing and nearly 85\% traditional medicines are plant derived [23]. Conservation of natural resources as well as its sustainable use is important in preservation of traditional knowledge.

Series of works have been done on ethno-botany work and ethno-ecology. However, GIS based mapping is indeed a novice idea. Spatial distribution using GIS happens to be new field of research and can be used in defining plants of a given region. Geo-visualization research in last 15 years directed considerable effort towards enhancing dynamic and interactive maps [24]. There are many remote places which are restricted for any physical reach for identification of plants. In this peculiar circumstance GIS could be a tool to address all these complexities using extrapolation techniques. Study area in the work happens to be least developed part of one of the poorest State in India. Thus, working for low socio-economic profile region will certainly be useful at larger scale and will bear extended benefits when the work will be thoroughly evaluated. The geographical maps (Figures 4-7, Figure 9) are primarily drawn on the basis of GPS co-ordinates collected during field visit. But there are many remote points which remained unreachable because of rainy seasons and geographical terrain and hence for such regions extrapolation was done. Using the map results one can directly approach for any particular plant and assesses its geographical health. It gives precise location of plants in the identified geographical territory.

\section{Conclusions}

The work would help researchers to find out the novel antimalarials towards open source drug discovery projects. GIS maps serve the purpose of emphasizing spatial distribution of plants. GIS mapping has got potential 
application in field of traditional knowledge mapping in times to come. Much work in this promising field has yet to be done. Integrating legends (of plant botanical names) with maps enhance readability of maps and it can be easily understood for the geographical features of the study region. The GIS based technique can be used to trace a given antimalarial geographically in a speedy manner. There exists alarming need to conserve and protect these important species for sustainable harvesting. A serious endeavor has to be taken to save these natural resources for the generations to come.

The work carried out in the region reveals that the plants recorded are highly valuable for antimalarial application and in future; bio-prospecting projects can be further initiated for sustainable harvesting towards developing antimalarial drug for curing malaria at large. A GIS based national mapping of antimalarials can be aimed and the task can be integrated with on-going umbrella projects bio-prospection of CSIR, New Delhi under domain of open source drug discovery for malaria (OSDDm). Some plants are nearly extinct in the region, the reason being change in land use pattern and shrinking of water bodies along with overharvesting of herbs. The bio-depletion of these antimalarials is due to the burgeoning population.

The GIS based approach can be made microscopic further by accommodating geographical features linked to growth of an antimalarial plant in a given area. Developing a link between information technology and ethnobotany will be a novice idea especially when world technology is changing rapidly. GIS has touched all walks of human interfaces and thus application of GIS in the research paper has been done to map antimalarial plants of any given locality. Traditional plant knowledge and plant spatial distribution can be linked further and its understanding is enhanced with GIS mappings. It is anticipated that in times to come GIS will be a dominant tool to understand ethnography.

\section{Acknowledgements}

We are highly indebted to the Open Source Drug Discovery Project for malaria of CSIR, New Delhi for providing financial assistance which kept constant high motivation throughout the work. We also acknowledge the computer laboratory facility at School of Computational \& Integrative Sciences and Centre for the Study of Regional Development, Jawaharlal Nehru University, New Delhi and is equally indebted to the Ministry of Environment \& Forest, MoEF Govt. of India for its continuous support towards making this work plausible.

\section{Conflict of Interest}

None declared.

\section{Prior Informed Consent and Ethic}

Not required.

\section{References}

[1] Kipgen, S. (2013) Bioprospecting and Identification of Anti-Malarial Compounds in Plants from Biodiversity-Rich Areas in India. CSIR-OSDD Natural Plant Products Project.

[2] Saxena, S., Pant, N., Jain, D.C. and Bhakuni, R.S. (2003) Antimalarial Agents from Plant Sources. Current Science, 85, 1314-1329.

[3] Verma, A.K., Kumar, M. and Bussmann, R.W. (2007) Medicinal Plants in an Urban Environment: The Medicinal Flora of Banares Hindu University, Varanasi, Uttar Pradesh. Journal of Ethnobiology and Ethnomedicine, 3, 35.

[4] Qayum, A., Lynn, A.M., Arya, R. and Jaiswal, S.K. (2013) GIS Integrated Epidemiological Indices for Risk Area Identification towards Malaria Control Measures. International Journal of Engineering and Advanced Technology (IJEAT), 2, 376-381.

[5] Auer, T., MacEachren, A.M., McCabe, C., Pezanowski, S. and Stryker, M. (2012) HerbariaViZ: A Web-Based Client-Server Interface for Mapping \& Exploring Flora Observation Data. Ecological Informatics Elsevier, 6, 93-110. http://dx.doi.org/10.1016/j.ecoinf.2010.09.001

[6] Murty, U.S.N. (2012) Epidemiological Modelling of Malaria in Endemic Zones of India. OSDD Malaria Project.

[7] Economic Policy Business Standard (2009) Uttar Pradesh Seeks MSP for Medicinal Plants. http://www.business-standard.com

[8] Srivastava, R. (2013) Underutilised Fruits: A Potential of Local food Resource. International Journal of Pharma \& Bio 
Sciences, 4, 1301-1305.

[9] Shankar, R., Deb, S. and Sharma, B.K. (2011) Antimalarial Plants of Northeast India: An Overview. Journal of Ayurveda \& Integrative Medicine (JAIM), 3, 10-16. http://dx.doi.org/10.4103/0975-9476.93940

[10] Bahekar, S. and Kale, R. (2013) Herbal Plants Used for the Treatment of Malaria-A Literature Review. Journal of Pharmacognosy and Phytochemistry, 1, 141-146.

[11] Pushpangadan, P. and Kumar, B. (2005) Ethnobotany, CBD, WTO and the Biodiversity Act of India. Ethnobotany, 17, $2-12$.

[12] Census of India (2011) Directorate of Census Operations Uttar Pradesh Administrative Atlas 2012. http://www.census2011.co.in/census/state/uttar+pradesh.html

[13] Economics and Statistics Division (2011) Govt. of Uttar Pradesh, India. http://updes.up.nic.in

[14] Srivastava, T.N. (1976) Flora Gorakhpurensis. Today \& Tomorrow’s Print. \& Publ., New Delhi.

[15] Duthie, J.F. (1960) Flora of Upper Gangetic Plains. Botanical Survey of India Publisher, Vol. I \& II.

[16] Kamaraj, C., et al. (2012) Antimalarial Activities of Medicinal Plants Traditionally Used in the Villages of Dharmapuri Regions of South India. Journal of Ethnopharmacology, 141, 796-802.

[17] Kumar V. and, Akhtar M. (2013) Ethanomedicinal Solanaceous Plants of Eastern Uttar Pradesh. Indian Journal of Life Sciences, 2, 95-98.

[18] Mishra, S.B., Dwivedi, S., Shashi, A. and Prajapati, K. (2008) Ethnomedicinal Uses of Some Plant Species by Ethnic and Rural Peoples of the Salem District of Tamilnadu with Special Reference to the Conservation of Vanishing Species. Ethnobotanical Leaflets, 12, 873-887.

[19] Pandey, A.K., Patra, A.K. and Shukla, P.K. (2005) Medicinal Plants in Satpura Plateau of Madhya Pradesh: Current Status and Future Prospects. Indian Forester, 131, 857-883.

[20] Pandey, A.K. and Tripathi, N.N. (2010) Diversity and Distribution of Aromatic Plants in Forests of Gorakhpur Division, U.P., India. Biological Forum: An International Journal, 2, 25-33.

[21] Pandey, A.K. and Tripathi, N.N. (2011) Aromatic Plants of Gorakhpur Division: Their Anti-Mycotic Properties \& Medicinal Value. International Journal of Pharmaceutical Science Review \& Research, 7, 142-147.

[22] Prakash, A. (2011) Uses of Some Threatened and Potential Ethnomedicinal Plants among the Tribals of Uttar Pradesh and Uttrakhand in India. National Conference on Forest Biodiversity: Earth's Living Treasure, 22 May 2011, 93-99.

[23] Jain, D.L., Baheti, A.M., Jain, S.R. and Khandelwal, K.R. (2010) Use of Medicinal Plants among Tribes in Satpuda Region of Dhule and Jalgaon Districts of Maharashtra-An Ethnobotanical Survey. Indian Journal of Traditional Knowledge, 9, 152-157.

[24] MacEachren, A.M., Crawford, S., Akella, M. and Lengerich, G. (2008) Design and Implementation of a Model, WebBased, GIS-Enabled Cancer Atlas. The Cartographic Journal, 45, 246-260. http://dx.doi.org/10.1179/174327708X347755 
Scientific Research Publishing (SCIRP) is one of the largest Open Access journal publishers. It is currently publishing more than 200 open access, online, peer-reviewed journals covering a wide range of academic disciplines. SCIRP serves the worldwide academic communities and contributes to the progress and application of science with its publication.

Other selected journals from SCIRP are listed as below. Submit your manuscript to us via either submit@scirp.org or Online Submission Portal.
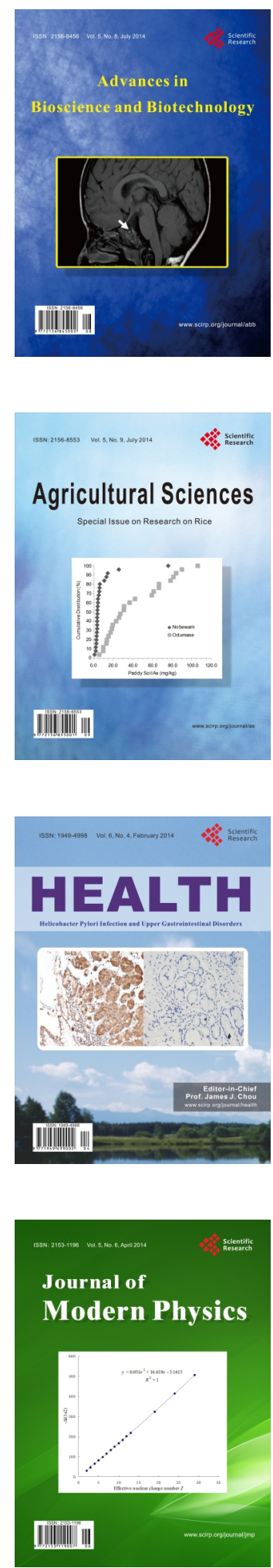
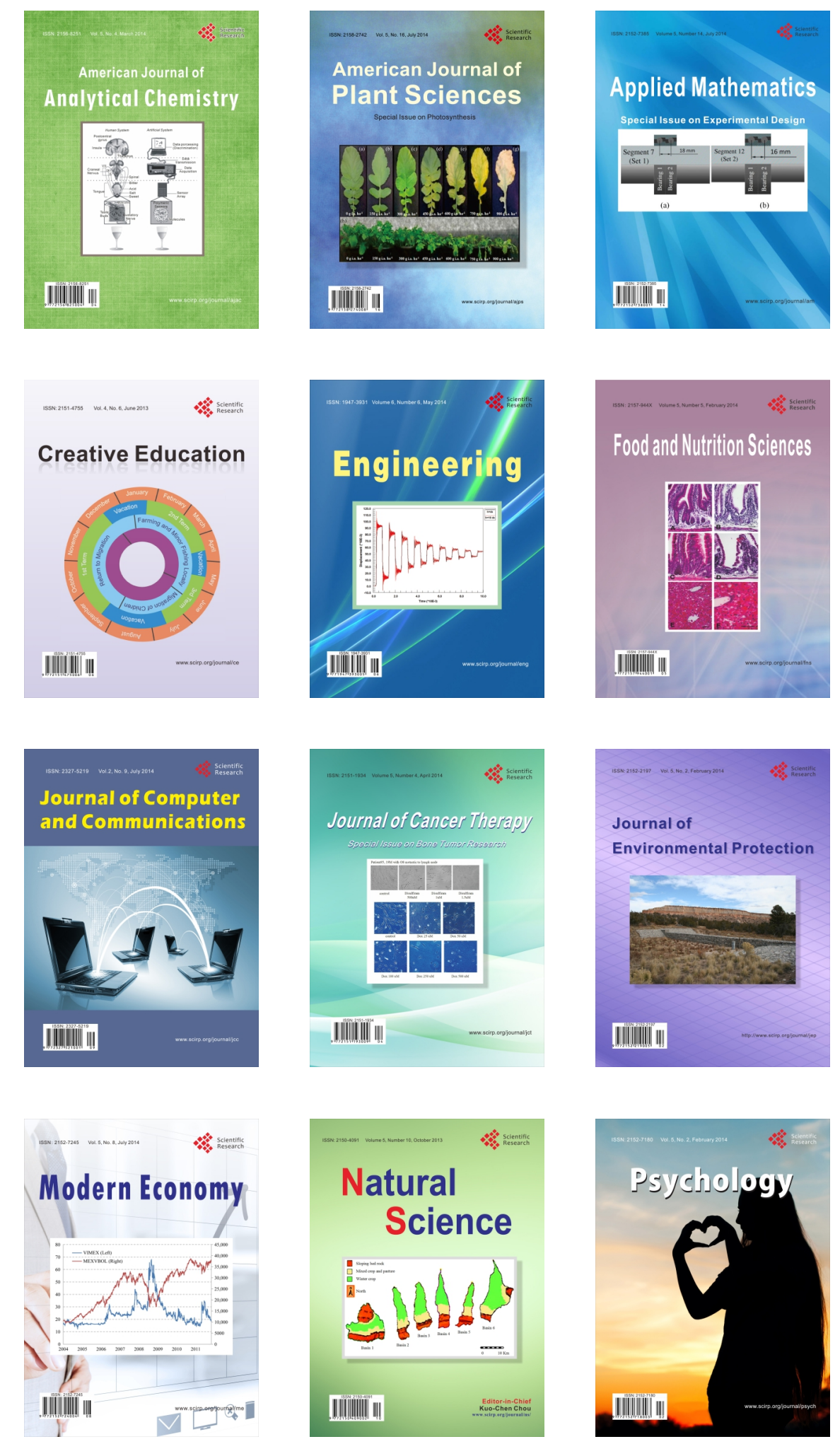